e-ISSN: $2595-5527$

10.32435/envsmoke.20214365-70

Volume 4, Issue 3

2021

\title{
INTERNAL ANATOMY OF THE OLIVE TURTLE (Lepidochelys olivacea)
}

ANATOMIA INTERNA DA TARTARUGA OLIVA (Lepidochelys olivacea)

\begin{abstract}
Gil Dutra Furtado ${ }^{1 *}$; Rute Cavalcante da Silva ${ }^{2}$; Patrícia Aguiar de Oliveira ${ }^{3}{ }^{\circ}$; Martin Lindsey Christoffersen ${ }^{4}$ (i)
\end{abstract}

\section{Abstract}

In this article, the internal organs of an olive sea turtle (Lepidochelys olivacea) were described. The autopsy was based on a methodological guide of "Virchow". The Cardiorespiratory, Digestive, Liver, Gallbladder, Pancreas, Spleen, Genito-Urinary System, and Endocrine System systems were observed. This description of the internal organs aimed to provide practice in anatomical identification and to provide didactic information for the students of the course in veterinary medicine.

Keywords: Chelonian. Olive turtle. Veterinary Medicine.

\section{Resumo}

Os órgãos internos de uma tartaruga marinha oliva (Lepidochelys olivacea) foram descritos. A metodologia utilizada na metodologia foi baseada no roteiro pré-determinado na técnica de "Virchow". Foram observados os Sistema Cardiorrespiratório, Digestivo e suas glândulas anexas, Baço, Sistema GenitalUrinário e Sistema Endócrino. Os objetivos foram os de proporcionar uma prática de identificação anatômica, trazendo informações didáticas para os educandos do curso de medicina veterinária.

Palavras-chave: Quelônio. Tartaruga oliva. Medicina veterinária

\section{Resumen}

Se describieron los órganos internos de una tortuga de olivo (Lepidochelys olivacea). Durante la autopsia de este queloniano, utilizamos la metodología basada en el guion predeterminado de la metodología "Virchow". Se observaron los sistemas cardiorrespiratorio, digestivo, hepático, vesicular, páncreas, bazo, sistema genitourinario y sistema endocrino. La descripción de los órganos internos tenía como objetivo proporcionar una práctica de identificación anatómica, así como brindar información didáctica a los estudiantes del curso de medicina veterinaria.

Palabras-chave: Queloniano. Tortuga de oliva. Medicina Veterinaria.
${ }^{1}$ Ph.D. in Psichobiology, Federal University of Rio Grande do Norte (UFRN); Veterinary Medicine, University Center Maurício de Nassau, Paraíba (UNINASSAU), João Pessoa, Brasil

${ }^{2}$ Undergraduate in Veterinary Medicine, UNIESP University Center, Cabedelo, Brasil

${ }^{3} \mathrm{Ph} . \mathrm{D}$. in Environmental Sciences, Federal University of Paraíba (UFPB); Professor of Veterinary Medicine, UNIESP, Cabedelo, Brasil

${ }^{4}$ Ph.D. in Biological Sciences(Zoology), University of São Paulo (USP); Professor at the UFPB, João Pessoa, Brasil

*Corresponding author: gdfurtado@ hotmail.com
Received: 15 Oct. 2021 Accepted: 16 Nov. 2021 Published: 30 Dec. 2021 


\section{Introduction}

$\mathrm{H}$ uman activity has resulted in the decline of populations of marine turtles worldwide. Degradation of the natural ecosystem, intense climatic oscillations, wounds caused during encounters with aquatic vessels, accidental deaths during commercial fishing, among other factors, are examples of what is happening to these animals nowadays (ALVARENGA et al., 2018).

Understanding the importance of these animals for the preservation of the aquatic environment lead us to question the environemntal effects of mankind on the remaining populations. The production of a management program for the conservation of marine turtles thus becomes important and necessary (SALES, 2017).

It is presently known that marine turtles help maintaining adequate levels of marine algae and positively influence the functioning of coral reefs (SALES, 2017).

The aim of this article is to describe the internal anatomy of an olive marine turtle necropsied by students of veterinary medicine at the University Center Maurício de Nassau (UNINASSAU/PB).

\section{Materials and Methods}

The necropsy of the marine turtle Lepidochelys olivacea (Eschscholtz, 1829) was done in the Animal Anatomy Lab, University Centre Maurício de Nassau (UNINASSAU - PB). The activities were recorded by the students participating in the project "VETERINARY EXPERIENCE AT PARAÍBA AQUARIUM. Veterinary actions, necropsy of cheloniid, and university extension activities".

This project, through the partnership signed between the aquarium and the educational institution a few years ago, allows the visitation to be carried out in a guided format by the aquarium technician in conjunction with the class teacher, so as to be a class experienced by the knowledge and actions of the caretakers in relation to the management, nutrition and behaviour of the animals that are either on display in the visitation circuit or in the rehabilitation centre of marine species, which in this case, the "patient" animals are rescued and after recovery, are reintroduced into the nature. In the case of death, the universities and competent authorities are contacted to decide on the use of the animal for study or, depending on the case, more specific analyses.

Literature revisions and searches for pertinent references published in electronic media were also conducted (FONSECA, 2002; GIL, 2011).

The animal was first evaluated as to its external integrity. After the removal of the outer carapace and plastron, all inner organs were examined and described.

All individuals involved in the necropsy were equipped with the standard safety equipment (ANDRADE et al., 2002; FURTADO et al., 2019). The methodological guide and techniques established by "Virchow" (VIRCHOW, 1875; WORK, 2000) were followed.

\section{Results and Discussion}

The marine olive turtle is a chelonian, in other words, "a reptile provided with a hull" (O'MALLEY, 2005). Oceanic turtles are ectothermic animals, with compact bodies, using their limbs as natatory devices, having a non-retractile neck, and do not have teeth. The hull is formed by a dorsal carapace and a ventral plastron, both being bone structures covered by corneal plates and serving to protect the internal organs (BOYER and BOYER, 2006; CUBAS and BAPTISTOTTE, 2007).

The carapace, plastron and skin of the animal were in good condition, without anormal growths, with only the presence of some barnacles.

The internal organs of the olive turtle are located in the coelomic cavity, placed between the plastron and the carapace, both ventrally and dorsally. Within this cavity lie the heart, the thyroid, the final portion of the trachea, the lung, the liver, the gallbladder, the spleen, the oesophagus, the stomach, the small intestine, the large intestine, the pancreas, the kidneys, the bladder, the adrenals, the testicles, the ovaries, and the oviduct (BOYER and BOYER, 2006; CUBAS and BAPTISTOTTE, 2007). 


\section{Cardiorespiratory System}

Inspecting the cardiovascular system, we find: the heart, that presented a smooth surface, a firm consistency, and a tanned colouring; the lung had a wrinkled surface, with a friable consistency and being the colour of coffee; the trachea had a smooth lumen and was white.

Being a reptile, the olive turtle is characterized as an ectothermic animal, depending on the ambient temperature in order to regulate its internal temperature. The cardiovascular system is thus very important and depends upon several factors that will contribute to determine the cardiac frequency (CF), such as the size of the chelonian, the ambient temperature, the saturation of oxygen in the blood, the respiratory ventilation, the postural or gravitational stress, the hemodynamic balance, and the body sensory stimulus (KIK and MITCHELL, 2005; MITCHELL, 2009).

Observing the opened body of the chelonian, the heart is located along a median line, covered by the pericardium (O'MALEY, 2005). The heart has three cardiac lobes, of which two are atria and one represents the ventriculus. The ventriculus has a compact and spongy myocardium, while the atria have thin walls separated by a septum (KIK and MITCHELL, 2005; VITT and CALDWELL, 2009).

Three sub-chambers are observed in the ventriculus, the cavum pulmonale (that extend cranially to the pulmonary artery), the cavum arteriosum and the cavum venosum (situated dorsally and that receive blood from the right and left atria, being connected by the interventricular canal) (KIK and MITCHELL, 2005).

In the respiratory system, the rate of oxygen consumption is smaller than in mammals, and this difference explains the low metabolic rate of chelonians (MOSLEY, 2005).

The trachea is formed by complete cartilaginous rings. The pair of spongy lungs occupy a large space in the dorsal half of the body cavity. They are surrounded by a pleural cavity, being separated from the ventral cavity only by the viscera and by a thin, non-muscular, post-pulmonary septum (O'MALEY, 2005).

\section{Digestive System}

When exploring the digestive system, we have seen that the oral cavity had a smooth mucosa, of a yellowish colour, without any food contents; the oesophagus had a rough mucosa, a yellow colour, and with sand found in its interior; the following digestive system corresponds to the beginning of the stomach and has a smooth mucosa, yellowish in colour, without our being able to identify its contents; the remaining part of the stomach had a smooth mucosa, being rose-coloured, and its contents were also not identified; the small intestine had a smooth mucosa, was rose-coloured, without contents; the large intestine had a smooth mucosa, being rose-coloured, and containing some faecal material.

The gastrointestinal tract of the turtle includes the mouth, oral cavity, oropharyngeal cavity, oesophagus, stomach, small intestine, large intestine, ending in a cloaca (MITCHELL and DIAZFIGUEROA, 2005).

The oesophagus is a tubular organ, membranemuscular, with longitudinal folds along its mucosa, that serve to connect the oropharyngeal region and the expanded portion of the stomach (PIZZUTTO et al., 2001; MAGALHÃES, 2010).

The function of the oesophagus is to transport food to the stomach (DIAZ-FIGUEROA and MITCHELL, 2006). The stomach occurs in the left lobe of the liver, having many rugosities and longitudinal folds in the mucosa. Gastro-oesophageal and pyloric valves can also be observed in the stomach (O'MALEY, 2005; CUBAS and BAPTISTOTTE, 2007).

The stomach is divided into the cardiac region, ground region, and pyloric region, that have the function of storing and digesting food by enzymatic reactions and mechanical processes (MITCHELL and DIAZ-FIGUEROA, 2005; PIZZUTTO et al., 2001; PINTO, 2006; MAGALHÃES et al., 2010).

The organ known as the small intestine is composed by a long, thin, tube, tangled along a portion of its length (OLIVEIRA et al., 1996; PINTO, 2006; CUBAS and BAPTISTOTTE, 2007; MAGALHÃES, 2010).

The main place for the absorption of nutrients lies at the end of the stomach and beginning of the duodenum (PIZZUTTO et al., 2001). Because the 
olive turtle is carnivorous, feeding on salps, fish, molluscs, crustaceans, bryozoans, tunicates, jellyfish and fish eggs, the intestine tends to be shorter than in herbivorous turtles (DIAZFIGUEROA and MITCHELL, 2006; CRUZ, 2017).

\section{Liver, gallbladder, pancreas, and spleen}

Examination of the liver indicated a wrinkled surface of fragile consistency, the colour of coffee; the gallbladder was whole and contained bile; the pancreas showed no alterations, and the spleen had a wrinkled surface, a firm consistency, and was coffee-coloured.

The liver and pancreas are adhered to the stomach and duodenum. Their function is to metabolize fats, proteins and glycogen, as well as to produce uric acid and adherent factors (MOSLEY, 2005; HERNANDEZDIVERS and COOPER, 2006; VITT and CALDWELL, 2009).

In chelonians, the liver represents 3 to $4 \%$ of the weight of the animal, being large and is located ventrally to the lungs. This organ has two lobes that surround the gallbladder on the right side (O'MALEY, 2005; HERNANDEZ-DIVERS and COOPER, 2006; CUBAS and BAPTISTOTTE, 2007; VITT and CALDWELL, 2009).

The pancreas is a small and diffuse gland associated with the stomach and duodenum (DIAZFIGUEROA and MITCHELL, 2006; VITT and CALDWELL, 2009).

The gallbladder is associated with the stomach and pancreas on the dorsal mesentery. It is usually ovoid, small, being reddish-brown in colour (GARNER, 2006; HERNANDEZ-DIVERS, 2006).

\section{Genito-Urinary System}

The kidneys had a wrinkled surface, of fragile consistency, yellow in colour; the bladder had a glandular mucosa, was rose-coloured, with no contents; the gonads had a smooth surface, a firm consistency, and a yellow colour.

The urinary tract of the olive turtle consists in a pair of kidneys, both connected to the bladder by a pair of ureters. The ureters are also connected to the cloaca by the urethra. The observed reproductive system includes the ovaries (but they could also be the testicles), that are connected to the urinary tract by the cloaca (HOLZ, 2006).
The kidneys of the olive turtle are located in the coelomic cavity, cranially relative to the pelvic girdle. They are flattened, lobulated, symmetrical, and located close to the gonads.

The bladder of the olive turtle has a thin and distensible wall (CANNY, 1998; REAVILL and SCHMIDT, 2010). Variations in the outer morphology have been described for different species (CANNY, 1998).

The paired gonads are located near the kidneys (BOYER and BOYER, 2006). They are well defined, and the male and female gonads are distinguished. They produce gametes and sexual hormones (VITT and CALDWELL, 2009). The ovary consists of a sac with thin walls, having the germinal cells between the inner and outer walls of the ovary. The follicles occur in great numbers, forming the visible part of the ovaries in gestational females (DENARDO, 2006; CUBAS and BAPTISTOTTE, 2007; VITT and CALDWELL, 2009). There is also an oviduct, divided into infundibulum, magnum, and isthmus, that have the function of forming the eggs (BOYER and BOYER, 2006; CUBAS and BAPTISTOTTE, 2007).

\section{Endocrine System}

The endocrine system is formed by numerous glands dispersed over the entire body (VITT and CALDWELL, 2009).

During the necropsy it was not possible to identify the thyroid gland. The adrenal glands showed no alterations.

As well as the pancreas and the gonads, organs that belong to the endocrine system, the thyroid is located close to the cardiac base (GARNER, 2006; RIVERA and LOCK, 2008; VITT and CALDWELL, 2009).

The thyroid gland acts on reproduction, growth, development, endocrine functions, and metabolic rate (RIVERA and LOCK, 2008; VITT and CALDWELL, 2009). The adrenals are pairs of bilateral, elongated organs, located in front of the kidneys in reptiles, having two types of tissues, the cortical and the medullar, that have distinct functions. The medullar portion produced adrenaline and noradrenaline, that affect the blood flow to the head, liver, kidneys, and muscles, particularly under stress reactions. The cortical tissue produces a variety of steroid hormones (VITT and CALDWELL, 2009). 


\section{Conclusions}

With the description of the internal organs of the marine olive turtle (Lepidochelys olivacea), students had the opportunity of understanding the physiology of the chelonian, as well as providing practice in anatomical identification and bringing didactic information for the students in the course of veterinary medicine. This necropsy was based on the technique of the predetermined sequence of "Virchow", which permitted the observation of the Cardiorespiratory System, the Digestive System, the Liver, the Gallbladder, the Pancreas, the Spleen, the Genito-Urinary System, and the Endocrine System.

\section{Acknowledgements}

We thank the company "Paraíba Aquarium" for their contribution and partnership in this technicalscientific development, as well as for their actions towards Environmental Education and for the Preservation of the Marine Environment. The senior author (M.L.C.) is supported by a productivity grant from National Council for Scientific and Technological Development (CNPq, Brazil).

\section{References}

ALVARENGA, F. S.; GIFFONI, B. B.; ANTONIO, A. S.; OLIVEIRA, V. A.; SILVA, B. M. G.; BECKER, J. H. Monitoramento de capturas incidentais de Chelonia mydas em redes de emalhe costeiras em Ubatuba, São Paulo, Brasil. In: jornada de pesquisa e conservação de tartarugas marinhas no Atlãtico Sul Ocidental, 8., Rio de Janeiro. Livro de resumos...[s.n.], 2018.

ANDRADE, A., PINTO, SC., and OLIVEIRA, RS., orgs. Animais de Laboratório: criação e experimentação [online]. Rio de Janeiro: Editora FIOCRUZ, 2002. 388 p.

BOYER, T. H.; BOYER, D. M. Turtles, tortoises ans terrapins. In: MADER, D.R.; Reptile Medicine and Surgery. 2. ed. St Louis: Saunders Elsevier, 2006, p. 78-99.

CANNY, C. Gross anatomy and imaging of the avian and reptilian urinary system. Seminars in avian and exotic pet medicine. v. 7, n. 2, p. 72-80, 1998.
CUBAS, P. H.; BAPTISTOTTE, C. Chelonia (tartaruga, cágado, jabuti). In: CUBAS, Z.S.; SILVA, J.C.R.; CATAO-DIAS J.L. Tratado de animais selvagens: Medicina Veterinária. São Paulo: Roca, 2007, p. 86119.

CRUZ, D. N. Avaliação do desenvolvimento de filhotes de tartaruga oliva (Lepidochelys olivacea) submetidas à enriquecimento ambiental. TCC (Trabalho de Conclusão de Curso) - FACULDADE PIO DÉCIMO. ARACAJU - SE, p. 36. 2017.

DENARDO, D. Reproductive biology. In: MADER, D.R.; Reptile Medicine and Surgery. $2^{\mathrm{a}}$ ed. St Louis: Saunders Elsevier, 2006, p. 376-390.

DIAZFIGUEROA, O.; MITCHELL, M.A. Gastrointestinal anatomy and physiology. In: MADER, D.R.; Reptile Medicine and Surgery. 2. ed. St Louis: Saunders Elsevier, 2006, p. 145-162.

FONSECA, J.J.S. Metodologia da pesquisa científica. Fortaleza: UEC, 2002.

FURTADO, G. D.; SOBRAL, F. E. S. S.; FURTADO, E. M. Pasos de apertura de las cavidades abdominal y torácica en una necropsia: revisión bibliográfica. Environmental Smoke, volume. 3, número 2 p. 3541, 2019.

GARNER, M.M. Overview of biopsy and necropsy techniques. In: MADER, D.R.; Reptile Medicine and Surgery. $2^{a}$ ed. St Louis: Saunders Elsevier, 2006, p. 569- 580.

GIL, A.C. Metodologia do ensino superior. 4. ed. São Paulo: Atlas, 2011.

HERNANDEZ-DIVERS, S.J. Diagnostic techniques. In: MADER, D.R.; Reptile Medicine and Surgery. $2^{\mathrm{a}}$ ed. St Louis: Saunders Elsevier, 2006, p. 490-532.

HERNANDEZ-DIVERS, S.J.; COOPER, J.E. Hepatic lipidosis. In: MADER, D.R.; Reptile Medicine and Surgery. $2^{\mathrm{a}}$ ed. St Louis: Saunders Elsevier, 2006, p. 806- 813.

HOLZ, P. Renal anatomy and physiology. In: MADER, D.R.; Reptile Medicine and Surgery. $2^{\mathrm{a}}$ ed. St Louis: Saunders Elsevier, 2006, p. 135-144. 
KIK, M.J.L.; MITCHELL M.A. Reptile cardiology: a review of anatomy and physiology, diagnostic approaches, and clinical disease. Seminars in Avian and Exotic Pet Medicine, v. 14, n. 1, p. 52-60, 2005.

MAGALHÃES, M.S.; FREITAS, M.L.; SILVA, N.B.; MOURA, C.E.B. Morfologia do tubo digestório da tartaruga verde (Chelonia mydas). Pesquisa Veterinária Brasileira. v. 30, n. 8, p. 676-684, 2010.

MARCOVALDI, M. A.; THOMÉ, J. C. A.; BELLINI, C.; SILVA, A. C. C. D.; SANTOS, A. J. B.; LIMA, E. H. S. M.; FEITOSA, R. S. C.; GOLDBERG, D.; LOPEZ, G. G.; MARCOVALDI, G. A. Conservação e Pesquisa das Tartarugas Marinhas no Nordeste Brasileiro pelo Projeto Tamar. In: Conservação de Tartarugas Marinhas no Nordeste do Brasil: Pesquisa, desafios e Perspectivas, Pernambuco: Editora Universitária da UFRPE, 2016, p. 15-50, 2016.

MITCHELL, M.A. Reptile cardiology. Veterinary Clinic of North America: Exotic Animal Practice. v. 12, p. 65-79, 2009.

MITCHELL, M.A.; DIAZ-FIGUEROA, O. Clinical Reptile Gastroenterology. Veterinary Clinics of North America Exotic Animal Practice. v. 8, p. 277-298, 2005.

MOSLEY, G.A.E. Anesthesia and analgesia in reptiles. Seminars in Avian and Exotic Pet Medicine. v. 14, n. 4, p. 243-262, 2005.

OLIVEIRA, G.M.; SANTOS, E.E.D., LUZ, V.L.F. 1996. Estudo morfológico do tubo digestivo de Podocnemis expansa (tartaruga-da-amazônia). In: XXI Congresso Brasileiro de Zoologia, 1996, Porto Alegre. Anais... Porto Alegre. 1996

O'MALLEY, B. Clinical anatomy and physiology of exotic species. Structure and functions of mammals, birds, reptiles and amphibians. Saint Louis: Elsevier Saunders, 2005, p.41-54.

PINTO, J.G.S. Aspectos Anatomo-Radiográficos e Tempo de Trânsito Gastrintestinal em Tracajá Podocnemis unifilis Troschel, 1848 (Testudines, Podocnemididae). 2006. 34f. Dissertação (Mestrado), Universidade Federal de Uberlândia, Minas Gerais, 2006.
PIZZUTTO, C.S.; MARIANA, A.N.B.; GUIMARÃES, M.A.B.; CORRÊA, S.H.R. Radiological anatomy and barium sulfate contrast transit time in the gastrointestinal tract of the red-footed tortoise (Geochelone carbonaria). Boletín de la Asociación Herpetológica Española. v. 12, n. 1, p. 32-36, 2001.

REAVILL, D.R.; SCHMIDT, R.E. Urinary Tract Diseases of Reptiles. Journal of Exotic Pet Medicine. v. 19, n. 4, p. 280-289, 2010.

RIVERA, S.; LOCK, B. The Reptilian Thyroid and Parathyroid Glands. Veterinary Clinics of North America Exotic Animal Practice. v. 11, p. 163-175, 2008.

SALES, G. Seguindo tartarugas e tubarões na análise de uma política pública para a conservação da natureza. Tese Doutorado, Universidade Federal de Santa Catarina, Centro Sócio-Econômico, Programa de Pós-Graduação em Administração. 498p, 2017.

VITT, L.J.; CALDWELL, J.P. Herpetology: an introductory biology of amphibians and reptiles. 3rd ed. Burlington (MA): Elsevier, 2009. p. 35-81.

VIRCHOW, R. Die Sektions Technik im Leichenhause des Charité-Krankenhauses. August Hirschwald, Berlin, 1875.

WORK, T. M. Sea Turtle Necropsy Manual For Biologists In Remote Refuges. United States Geological Survey, National Wildlife Health Center, Hawaii Field Station. 2000.

UNGER, R.J.G. Regimes de Informação na Sociedade da Informação: uma Contribuição para a Gestão da Informação. 2006. Dissertação (Mestrado em Ciência da Informação). Rio de Janeiro: Universidade Federal Fluminense, 2006. 108p. Disponível em:

http://www. isafreire.pro.br/site/documentos/dess ertacao/dissertacao_roberto_unger.pdf.

WERSIG, G., NEVELING, U. The phenomena of interest to information science. The Information Scientist. v.9, n.4, p.127-140, 1975.

WIKIPÉDIA, Brasil. Disponível em: https://pt.wikipedia.org/wiki/Brasil. Acesso em 06 fev. 2021. 